Aksiologiya: Jurnal Pengabdian Kepada Masyarakat

Vol.4, No.2, Agustus $2020 \mathrm{Hal} 213$ - 220

ISSN 2528-4967 (print) dan ISSN 2548-219X (online)

\title{
Penggunaan Prezi untuk Meningkatkan Keterampilan Mengembangkan Multimedia TAVAGIS Kurikulum 2013 Bagi Guru Sekolah Dasar
}

\author{
Agatha Kristi Pramudika Sari ${ }^{1}$, Dyah Puteria Wati ${ }^{2}$ \\ 1,2STKIP Muhammadiyah Kuningan \\ Email: pramudika_sari@upmk.ac.id'1,d.puteriawati@gmail.com²
}

\begin{abstract}
ABSTRAK
Kegiatan ini bertujuan untuk mengetahui peningkatan keterampilan mengemabngkan multimedia TAVAGIS sebelum dan sesudah menggunakan Prezi kurikulum 2013 bagi guru sekolah dasar di Kabupaten Kuningan. Kegiatan ini terlaksana untuk mengatasi permsalahan guru mengenai kurangnya penguasaan IT dalam pembelajaran kurikulum 2013. Metode pelaksanaan kegiatan ini terdiri dari beberapa tahap yaitu: 1) perencanaan yang meliputi survei mitra, lisensi pelatihan, penyusunan modul pelatihan, persiapan pelatihan dan koordinasi,serta sosialisasi program, 2) pelaksanaan kegiatan PKM yang meliputi pelatihan pembuatan multimedia TAVAGIS berbasis Prezi serta pendampingan penggunaan multimedia yang telah dibuat, 3) evaluasi dan tindak lanjut. Berdasarkan hasil dan pembahasan, dapat disimpulkan bahwa keterampilan mengembangkan multimedia TAVAGIS kurikulum 2013 pada guru sekolah dasar sebelum menggunakan Prezi memperoleh prosentase skor sebesar 53,74\% dalam kategori cukup dan sesudah menggunakan Prezi memperoleh prosentase skor sebesar 89,52\% dalam kategori sangat baik. Data tersebut menyatakan bahwa terjadi peningkatan keterampilan mengembangkan multimedia TAVAGIS kurikulum 2013 pada guru sekolah dasar sebesar 35,78\%.
\end{abstract}

Kata kunci: Keterampilan, Multimedia, TAVAGIS, Prezi, Sekolah Dasar

\section{Use of Prezi to Improve Skills in Developing 2013 TAVAGIS Multimedia Curriculum for Elementary School Teachers}

\begin{abstract}
This activity aims to find out the improvement of TAVAGIS multimedia skills before and after using the 2013 Prezi curriculum for elementary school teachers in Kuningan District. This activity was carried out to overcome the teacher's problem regarding the lack of mastery of IT in 2013 curriculum learning. The method of implementing this activity consisted of several stages, namely: 1) planning which included a survey of partners, training licenses, preparation of training modules, preparation of training and coordination, and program socialization, 2) the implementation of PKM activities which include training on making TAVAGIS multimedia based on Prezi as well as assisting the use of multimedia that has been made; 3) evaluation and follow-up. Based on the results and discussion, it can be concluded that the skills of developing 2013 TAVAGIS multimedia curriculum in elementary school teachers before using Prezi obtained a percentage score of $53.74 \%$ in the sufficient category and after using Prezi obtained a percentage score of $89.52 \%$ in the very good category. The data states that there is an increase in skills in developing 2013 TAVAGIS multimedia curriculum for elementary school teachers by $35.78 \%$.
\end{abstract}

Keywords: Skills, Multimedia, TAVAGIS, Prezi, Elementary School

Copyright (C) 2020, Aksiologiya: Jurnal Pengabdian Kepada Masyarakat.

http://journal.um-surabaya.ac.id/index.php/Axiologiya/index 


\section{PENDAHULUAN}

Kurikulum yang sedang dilaksanakan di sekolah dasar saat ini di Indonesia adalah kurikulum 2013. Kurikulum 2013 sudah dilaksanakan secara terbatas di beberapa sekolah. Guru dan kepala sekolah sudah dibekali melalui pendidikan dan pelatihan implementasi kurikulum 2013 sekaligus telah disediakan pula buku-bukunya. Prinsip pengembangan Kurikulum 2013 salah satunya adalah berpusat pada potensi, perkembangan, kebutuhan, dan kepentingan peserta didik dan lingkungannya. Kurikulum dikembangkan berdasarkan prinsip bahwa peserta didik berada pada posisi sentral dan aktif dalam belajar (Kemendikbud, 2013). Untuk menghadapi tuntutan bahwa pembelajaran harus berpusat kepada siswa dan mengutamakan keaktifan siswa, maka guru dituntut untuk menggunakan media pembelajaran yang menarik yang sesuai dengan perkembangan zaman. Salah satu cara guru untuk mengikuti perkembangan zaman di era teknologi ini yaitu meningkatkan kapasitas diri dalam mengoperasikan perangkat komputer.

Perkembangan IT telah membawa pengaruh besar dalam proses pembelajaran sekalipun di sekolah dasar. Tersedianya fasilitas komputer dan internet di sekolah maupun di rumah memungkinkan peserta didik untuk belajar kapan dan di mana saja dengan lingkupyang sangatluas karena semua informasi yang di inginkan dapat kita peroleh dengan mengakses internet. Oleh karena itu, guru harus mengembangkan keterampilan membuatmedia pembelajaran berbasis IT untuk memacu keaktifan siswa pada saat pembelajaran. Hal tersebut sejalan dengan (Rumidjan, Sumanto, Sukamti, \& Sugiharti, 2017) bahwa keterampilan pengembangan desain dan pembuatan media pembelajaran yang dimiliki guru akan menghasilkan benda yang dapat digunakan sebagai media pembelajaran yang dapat memungkinkan murid menjadi aktif, kreatif, dan menyenangkan dalam kegiatan belajarnya.

Pada umumnya pembelajaran SD di wilayah Kabupaten Kuningan masih terpaku kepada buku teks saja, baik buku guru maupun buku siswa. Hal tersebut dapat berpengaruh terhadap tingkat keaktifan siswa dalam belajar dan juga secara tidak sadar dapat menyebabkan terjadinya pembelajaran yang berpusat pada guru. Berdasarkan penelitian yang dilakukan oleh (Sari \& Falah, 2018) menyatakan bahwa tingkat stres level siswa pada fullday school lebih tinggi dari pada half day school. Maka multimedia TAVAGIS berbasis Prezi juga dapat digunakan sebagai alternatif untuk mengurangi stress level siswa, khususnya di sekolah dasar. Suradijono seperti dikutip (Sari \& Wati, 2019b) pembelajaran berbasis komputer (courseware) bila dibuat dengan baik terbukti dapat meningkatkan proses belajar pada diri seseorang. Seiringkemajuanteknologi, guru dapat menggunakan berbagai media sesuai dengan kebutuhan dan tujuan pembelajaran. Selain guru perlu meningkatkan keahlian membuat multimedia pembelajaran, guru juga 
harus memperhatikan aspek situasi sehingga suasana didalam kelas tidak jenuh (Falah, 2017). Multimedia pembelajaran berguna untuk menyalurkan pesan (pengetahuan, keterampilan, dan sikap) serta dapat merangsang pilihan, perasaan, perhatian, dan kemauan siswa sehingga secara sengaja proses belajar, bertujuan, dan terkendali (Daryanto, 2011). Menurut Kustiono (2010) kata "multimedia" dapat diartikan sebagai perpaduan harmonis antara berbagai media baik teks (regular maupun hypertext), gambar, grafik, audio, video/film, dan animasi, yang dikemas secara sinergis untuk mencapai tujuan (pembelajaran) tertentu. Untuk menyusun multimedia berbasis IT yang menarik, efektif, dan fleksibel perlu adanya pelatihan khusus disertai dengan pendampingan penerapannya sehingga dapat memperbaiki proses pembelajaran dengan maksimal (Wati, Sahrir, \& Lutfi, 2018).

Salah satu upaya untuk membantu meningkatkan keterampilan guru membuat media berbasis IT khususnya di sekolah dasar dalam rangka menunjang pembelajaran kurikulum 2013 adalah melaksanakan kegiatan Pengabdian kepada Masyarakat (PKM) berupa Pelatihan Pembuatan Multimedia TAVAGIS (Text, Audio, Video, Animasi, Graph, Interactivity, and Special Effects) Berbasis Prezi dalam Pembelajaran Kurikulum 2013 bagi guru Sekolah Dasar di Kabupaten Kuningan. Aplikasi Prezi merupakan salah satu program yang dapat digunakan untuk membuat multimedia TAVAGIS (Teks, Audio,
Video, Animasi, Graph, Interacivity, and Spesial Effect) yang menarik untuk pembelajaran. Prezi adalah sebuah perangkat lunak untuk presentasi berbasis internet (SaaS). Selain untuk presentasi, Prezi juga dapat digunakan sebagai alat untuk mengeksplorasi dan berbagi ide di atas kanvas virtual. Prezi menjadi unggul karena program ini menggunakan Zooming User Interface (ZUI), yang memungkinkan pengguna Prezi untuk memperbesar dan memperkecil tampilan media presentasi yang dibuat (Rusyfian, 2016). Prezi digunakan sebagai alat untuk membuat presentasi dalam bentuk linier maupun non-linier, yaitu presentasi terstruktur sebagai contoh dari presentasi linier, atau presentasi berbentuk peta-pikiran (mindmap) sebagai contoh dari presentasi nonlinier. Program ini dibuat melalui komputer dan dapat diakses pada smartphone berbasis android (Sari \& Wati, 2019)

Kegiatan Program PKM ini dimaksudkan untuk menyiapkan guru-guru, khususnya difokuskan untuk guru Sekolah dasar kelas 4 seKecamatan Kuningan yang berjumlah 49 peserta dalam membuat dan mengimplementasikan multimedia TAVAGIS berbasis Prezi.

\section{METODE PELAKSANAAN}

Kegiatan PKM ini dilaksanakan pada tanggal 19 Juli sampai dengan 27 Juli 2019 di kampus STKIP Muhammadiyah Kuningan yang beralamat di Jalan Moertasiah Soepomo no 28 B Kabupaten Kuningan. Khalayak sasaran dalam 
program PKM ini adalah guru kelas 4 se-Kecamatan Kuningan. Adapun peserta yang dapat hadir dalam kegiatan ini adalah 49 peserta dari berbagai SD yang dinaungi oleh UPTD Pendidikan Kecamatan Kuningan baik swasta maupun negeri. Metode pelaksanaan kegiatan menjelaskan tahapan atau langkah-langkah dalam melaksanakan pelatihan pembuatan dan pendampingan penerapan multimedia TAVAGIS (Teks, Audio, Video, Animasi, Graph, Interacivity, and Spesial Effect) berbasis Prezi dalam pembelajaran Kurikulum 2013 bagi guru Sekolah Dasar di Kabupaten Kuningan. Adapun alur pelaksanaan kegiatan PKM ini adalah sebagai berikut.

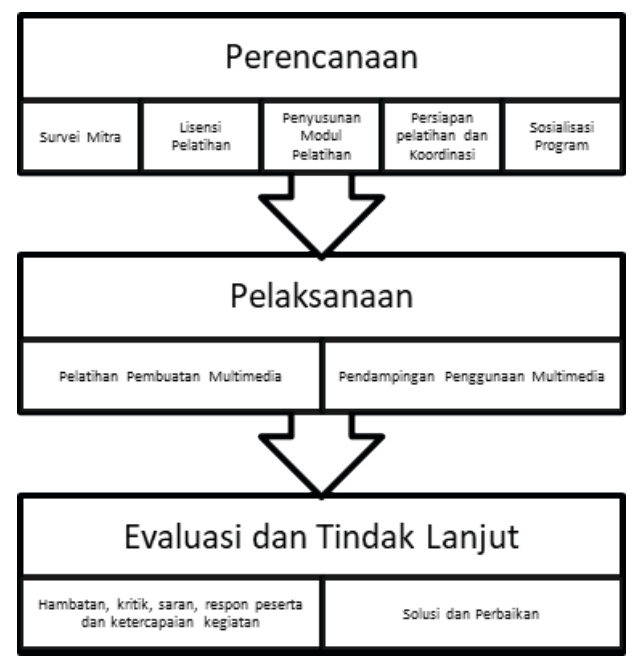

Gambar 1. Alur kegiatan PKM

\section{HASIL DAN PEMBAHASAN}

Kegiatan pelatihan pembuatan dan pendampingan penerapan Multimedia TAVAGIS berbasis Prezi yang berjalan selama bulan Juli 2019 sampai dengan Agustus 2019 berjalan dengan lancar. Teknik pengambilan data ketercapaian kegiatan dilakukan dengan observasi dan pengisian angket respon guru terhadap kegiatan.

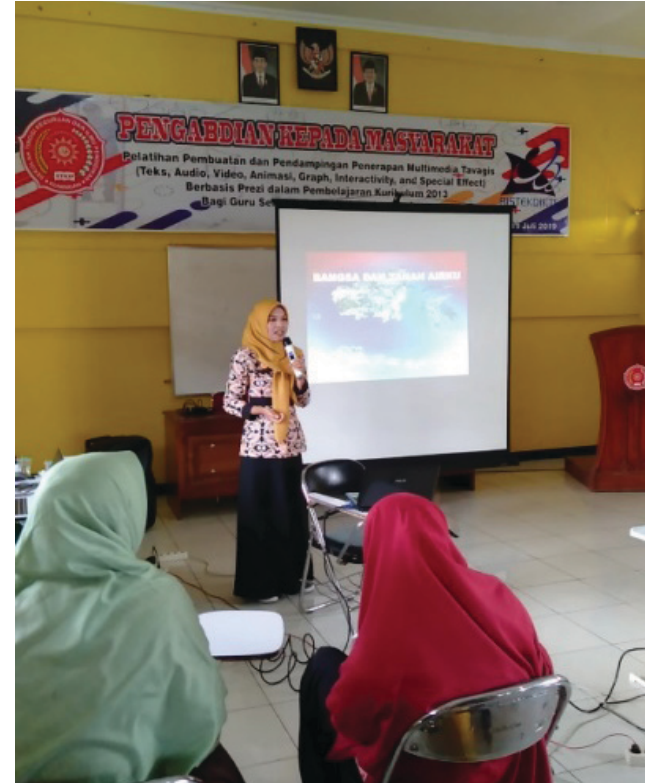

Gambar 2. Foto peserta kegiatan sedang mempresentasikan multimedia

Data pertama diambil dari hasil observasi. Observasi dilakukan untuk menggambarkan keterlaksanaan kegiatan PKM, yaitu berupa aktivitas peserta dan proses kegiatan, termasuk hambatan maupun permasalahan yang munculpadasaatkegiatanberlangsung. Berdasarkan data observasi, hasil yang dicapai dalam kegiatan Program Kemitraan Masyarakat (PKM) ini sebagai berikut:

1. Masing-masing skor prosentase yang dilakukan oleh ketiga observer yaitu Ketua LPKM STKIP Muhammadiyah Kuningan dengan skor 88,3\%, Ketua Pelaksana PKM dengan skor 90\% dan anggota pelaksana PKM dengan skor $85 \%$. Rata-rata skor hasil observasi keterlaksanaan kegiatan yaitu $87,8 \%$ artinya terlaksana dengan baik.

2. Berdasarkan hasil observasi yang dilakukan oleh ketiga observer tersebut, terdapat temuan-temuan 
antara lain jumlah peserta yang hadir sesuai dengan target, peserta pelatihan cepat memahami materi, suasana pelatihan interaktif dan menyenangkan, sarana dan prasarana terpenuhi sesuai yang diharapkan, modul yang dibagikan dapat membantu peserta maupun pelatih dalam kegiatan, pelatihan terlaksana sesuai jadwal yang ditentukan, terjadi interaksi antara peserta dan pelatih, dan materi yang ditargetkan tersampaikan dengan baik.

3. Berdasarkan hasil observasi ditemui juga beberapa kendala dalam pelaksanaan kegiatan antara lain ada beberapa peserta yang sangat kesulitan untuk mengoperasikan komputer, serta ada beberapa peserta yang belum menyelesaikan produk pelatihan Prezi yang diberikan oleh tutor. Solusi untuk mengatasi kendala yang terjadi antara lain dengan mendampingi guru yang kesulitan dalam mengoperasikan komputer oleh tutor pendamping.

Data kedua diambil dari hasil angket keterampilan mengembangkan multimedia TAVAGIS kurikulum 2013 sebelum dan sesudah mengenal Prezi. Angket tersebut diisi oleh peserta kegiatan sebanyak 49 responden. Penyebaran angket dilakukan untuk mengetahui seberapa besar peningkatan keterampilan mengembangkan multimedia TAVAGIS kurikulum 2013. Adapun hasil jawaban angket sebagai berikut.
Tabel 1. Hasil Angket Peningkatan

Keterampilan Mengembangkan

Multimedia

\begin{tabular}{|c|l|c|c|}
\hline \multirow{2}{*}{ No } & \multirow{2}{*}{ Indikator } & \multicolumn{2}{c|}{$\begin{array}{c}\text { Hasil Jawaban } \\
\text { Responden (\%) }\end{array}$} \\
\cline { 3 - 4 } & & Sebelum & Sesudah \\
\hline 1 & $\begin{array}{l}\text { Pengetahuan } \\
\text { mitra tentang } \\
\text { Multimedia } \\
\text { TAVAGIS } \\
\text { berbasis Prezi }\end{array}$ & 54,69 & 91,02 \\
\hline 2 & $\begin{array}{l}\text { Pemahaman } \\
\text { Mitra terhadap } \\
\text { Multimedia } \\
\text { TAVAGIS } \\
\text { berbasis Prezi }\end{array}$ & 54,90 & 90,20 \\
\hline 3 & $\begin{array}{l}\text { Keterampilan } \\
\text { Mitra dalam } \\
\text { membuat dan } \\
\text { menerapkan } \\
\text { Multimedia } \\
\text { TAVAGIS } \\
\text { berbasis Prezi }\end{array}$ & 51,63 & 87,35 \\
\hline & & \\
\hline Rata-Rata & $\mathbf{5 3 , 7 4}$ & $\mathbf{8 9 , 5 2}$ \\
\hline
\end{tabular}

Adapun kriteria pencapaian prosentase skor dari tabel 1 adalah katagori sangat baik apabila prosentase mencapai 81-100\%, kategori baik apabila prosentase mencapai $61-80 \%$, kategori cukup baik apabila prosentase mencapai 41-60\%, kategori kurang baik apabila prosenase mencapai 21$40 \%$, dan kategori sangat kurang baik apabila prosentase mencapai $0-20 \%$. Berdasarkan tabel 1 tersebut dapat diuraikan dalam penjelasan sebagai berikut :

1. Indikator pertama tentang pengetahuan mitra tentang Multimedia TAVAGIS berbasis Prezi, mencapai prosentase sebesar 91,02\% dalam kategori sangat baik. Adapun hasil 
tersebut merupakan rata-rata prosentase skor dari 4 pernyataan yaitu (a) Modul tentang Multimedia TAVAGIS berbasis Prezi yang didistribusikan dan ditayangkan membantu dalam memahami materi pada saat pelatihan maupun pada saat di lapangan. Mencapai prosentase $88,98 \%$; (b) Cara narasumber menyampaikan materi, mudah dimengerti, sehingga mencukupi pengetahuan tentang Multimedia TAVAGIS berbasis Prezi sebelum mulai membuatnya. Mencapai prosentase 89,39\%; (c) Pelatihan tentang Multimedia TAVAGIS berbasis Prezi ini memberikan pengetahuandanide-ideyangdapat diterapkan di lapangan. Mencapai prosentase 88,98\%; (d) Pelatihan tentang Multimedia TAVAGIS berbasis Prezi ini meningkatkan keahlian dan pengetahuan teknis serta keterampilan baru dalam menggunakan alat peraga. Mencapai prosentase 96,73\%. Prosentase tersebut berdasarkan jawaban dari 49 responden.

2. Indikator kedua tentang pemahaman mitra terhadap Multimedia TAVAGIS berbasis Prezi, mencapai prosentase sebesar 90,20\% dalam kategori sangat baik. Adapun hasil tersebut merupakan rata-rata prosentase skor dari 4 pernyataan yaitu (a) kemudahan membuat akun Prezi mencapai prosentase $91,02 \%$; (b) variasi pilihan dalam template dan lisensi yang dapat digunakan mencapai prosentase $90,61 \%$; (c)
Tools yang terdapat dalam Prezi mudah dipahami dan digunakan. Mencapai prosentase 95,92\%; (d) Multimedia TAVAGIS berbasis Prezi dapat menampilkan kontent pembelajaran dengan jelas sehingga siswa mudah memahami materi pembelajaran mencapai prosentase $83,27 \%$. Prosentase tersebut berdasarkan jawaban dari 49 responden.

3. Indikator ketiga tentang keterampilan mitra dalam membuat dan menerapkan Multimedia TAVAGIS berbasis Prezi, mencapai prosentase sebesar 87,35\% dalam kategori sangat baik. Adapun hasil tersebut merupakan rata-rata prosentase skor dari 4 pernyataan yaitu (a) Terjadi peningkatan keterampilan mengoperasikan komputer dalam diri setelah mengikuti pelatihan. Mencapai prosentase $83,67 \%$; (b) terampil mengkolaborasikan Multimedia TAVAGIS berbasis Prezi antar guru meskipun lokasi sekolah berbeda, sehingga luaran atau hasil pelatihan berupa Multimedia TAVAGIS berbasis Prezi pada akun masing-masing dapat digunakan mencapai prosentase 92,65\%; (c) Multimedia TAVAGIS berbasis Prezi mudah diimplementasikan di sekolah. Mencapai prosentase $81,22 \%$; $\quad$ (d) Penggunaan multimedia TAVAGIS berbasis Prezi menjadikan pembelajaran lebih terstruktur mencapai prosentase 91,84\%. Prosentase tersebut berdasarkan jawaban dari 
49 responden.

Berdasarkan paparan indikator, dapat dijelaskan bahwa keterampilan mengembangkan multimedia TAVAGIS kurikulum 2013 pada guru sekolah dasar sebelum menggunakan Prezi memperoleh prosentase skor sebesar 53,74\% dalam kategori cukup dan sesudah menggunakan Prezi memperoleh prosentase skor sebesar 89,52\% dalam kategori sangat baik. Datatersebutdapatdisimpulkanbahwa Terjadi peningkatan keterampilan mengembangkan multimedia TAVAGIS kurikulum 2013 pada guru sekolah dasar sebesar 35,78\%.

\section{SIMPULAN}

Berdasarkan hasil dan pembahasan, dapat disimpulkan bahwa keterampilan mengembangkan multimedia TAVAGIS kurikulum 2013 pada guru sekolah dasar sebelum menggunakan Prezi memperoleh prosentase skor sebesar 53,74\% dalam kategori cukup dan sesudah menggunakan Prezi memperoleh prosentase skor sebesar $89,52 \%$ dalam kategori sangat baik. Data tersebut menyatakan bahwaterjadipeningkatan keterampilan mengembangkan multimedia TAVAGIS kurikulum 2013 pada guru sekolah dasar sebesar $35,78 \%$.

\section{Ucapan Terima Kasih}

Terimakasih kepada DRPM Kemenristekdikti yang memberikan hibah melalui skema Program Kemitraan Masyarakat (PKM), seluruh civitas akademika STKIP Muhammadiyah Kuningan, para pihak yang telah membantu penulisan karya tulis ilmiah ini, terutama kepada para penulis sebelumnya yang terdapat di dalam daftar pustaka (nama-nama peneliti yang terdapat di referensi), atas publikasi ilmiah sebelumnya yang diterbitkan dan disediakan secara terbuka (open source), dan juga reviewer dan editor dari jurnal ini, sehingga dapat mempublikasikan topik ini.

\section{DAFTAR PUSTAKA}

Daryanto. (2011). Media Pembelajaran. Bandung. Sarana Tutorial Nurani Sejahtera.

Falah, I. F. (2017). Pengenalan kosakata bahasa inggris melalui lagu. Jurnal Pelita PAUD, 1(2).

Kemendikbud. (2013). Implementasi Kurikulum 2013 Pedoman Umum Pembelajaran. Permendikbud, 81(A), 1-97.

Kustiono. (2010) Media Pembelajaran Konsep, Nilai Edukatif, Klasifikasi, Praktek, Pemanfaatan dan Pengembangan. Semarang: UNNES Press.

Rumidjan, Sumanto, Sukamti, \& Sugiharti, S. (2017). Pelatihan Pembuatan Media Grafis Dan Media Papan Untuk Meningkatkan Kualitas PembelajaranBagiGuruSekolah Dasar. Abdimas Pedagogi, 1(1), 77-81.

Sari, A. K. P., \& Falah, I. F. (2018). Perbedaan Stress Level Siswa Sekolah Dasar Antara Full-Day Dan Half-Day School. 4(2), 142-148.

Sari, A. K. P., \& Wati, D. P. (2019a). Penerapan Multimedia TAVAGIS Berbasis Prezi dalam Pembelajaran Kurikulum 2013 bagi Guru Sekolah Dasar di Kabupaten Kuningan. Jurnal 
Pengabdian Pada Masyarakat, 4(3), 369-380. https://doi. org/10.30653/002.201943.185

Sari, A. K. P., \& Wati, D. P. (2019b). Respon guru terhadap pelatihan pembuatan multimedia TAVAGIS berbasis prezi dalam pembelajaran kurikulum 2013. Seminar Nasional Hasil Pengabdian Kepada Masyarakat, (September), 567-576. Universitas Ahmad Dahlan.

Wati, D. P., Sahrir, D. C., \& Lutfi, A. F. (2018). Pelatihan Pembuatan dan Pendampingan Penerapan Multimedia Genggam Si Dio (Camtasia Studio) Berbasis Android bagi Tutor PKBM di Kabupaten Kuningan. In Jurnal Pengabdian Pada Masyarakat (Vol. 3). https://doi. org/10.30653/002.201832.74 